\title{
HUBUNGAN SANITASI RUMAH DENGAN KEJADIAN PENYAKIT TBC DI WILAYAH KERJA PUSKESMAS PACARKELING KOTA SURABAYA TAHUN 2018
}

Wahyuningtyas, Umi Rahayu, Imam Thohari

\begin{abstract}
ABSTRAK
Di Indonesia, rumah yang dihuni oleh masyarakat ternyata baru mencapai 50,79 \% yang memenuhi kriteria sehat. Pemukiman di wilayah Puskesmas Pacarkeling berada di wilayah Surabaya Timur dan termasuk daerah perkotaan dengan tipe pemukiman padat. Berdasarkan survey yang telah dilakukan kondisi rumah di daerah tersebut masih saling berdempetan satu sama lain, terletak di gang-gang yang cukup sempit. Tujuan penelitian ini adalah untuk mengetahui hubungan sanitasi rumah dengan kejadian penyakit TBC di wilayah kerja Puskesmas Pacarkeling Kota Surabaya.

Metode penelitian yang digunakan adalah penelitian analitik dengan menggunakan pendekatan Case Control. Pengumpulan data dilakukan dengan observasi dan pengukuran. Sampel dalam penelitian ini sebanyak 42 rumah penderita TBC dan 42 rumah tetangga penderita TBC (sebagai kontrol). Dalam penelitian ini digunakan uji Chi-Square, untuk mengetahui adanya hubungan antar variabel. Yang menggunakan derajat kesalahan (a) $=0,05$.

Hasil penelitian menyimpulkan bahwa ada hubungan antara ventilasi $(P$ $0,006<0,05)$, suhu $(P 0,001<0,05)$, kelembaban $(P 0,001<0,05)$, pencahayaan $(P 0,001<0,05)$, kebiasaan membuka jendela $(P 0,001<$ $0,05)$, dan sanitasi rumah $(\mathrm{P} 0,000<0,05)$ dengan kejadian penyakit TBC di wilayah kerja Puskesmas Pacarkeling Kota Surabaya. Selain itu tidak ada hubungan antara kepadatan hunian rumah dengan kejadian penyakit TBC di wilayah kerja Puskesmas Pacarkeling Kota Surabaya (P 0,053>0,05). Sebaiknya luas ventilai $10 \%$ dari luas lantai serta penghuni rutin membuka jendela. Selain itu agar penelitian ini dapat digunakan sebagai bahan referensi atau pertimbangan yang terkait dengan penelitian sejenis.

Kata Kunci: Sanitasi rumah, TBC
\end{abstract}

\section{A. Pendahuluan}

Perkembangan kota yaitu proses perubahan kota dari suatu keadaan ke keadaan yang lain dalam waktu yang berbeda. Kondisi tekanan ekonomi dan kepadatan tempat tinggal bagi kaum urban memaksa mereka untuk menempati daerah-daerah pinggiran (s/um area) hingga membentuk lingkungan 
pemukiman kumuh (Crysta, 2017).

Tuberkulosis merupakan salah satu penyakit menular yang mematikan dan hingga sekarang masih menjadi perhatian masyarakat dunia. Berdasarkan laporan World Health Organization (WHO), bahwa pada tahun 2013 Indonesia masuk ke dalam negara dengan beban tinggi tuberkulosis yang menduduki peringkat ke-4 sebagai negara penyumbang penyakit tuberkulosis setelah India, Cina, dan Afrika Selatan (WHO, 2014).

Berdasarkan Data Profil kesehatan Kementerian Kesehatan Republik Indonesia Tahun 2017, jumlah kasus TBC di Provinsi Jawa Timur yaitu 48.183 penderita. Sedangkan jumlah kasus penyakit TBC di Kota Surabaya menduduki peringkat pertama pada tahun 2017 yaitu sebanyak 6.338 penderita. Dan di wilayah kerja puskesmas Pacarkeling, jumlah kasus baru penyakit TBC sebanyak 73 orang dari 2 kelurahan yaitu kelurahan Pacarkeling dan Kelurahan Pacarkembang, yang mana termasuk ke dalam 10 wilayah terbesar dengan kejadian penyakit TBC di Kota Surabaya. Sedangkan pada tahun 2017 mengalami penurunan kasus yaitu sebesar 47 kasus, dengan kasus tertinggi berada pada Kelurahan Pacarkembang dengan kasus sebesar 33 kasus, dan sisanya sebanyak 14 kasus pada Kelurahan Pacarkeling.

Pemukiman di wilayah Puskesmas Pacarkeling berada di wilayah Surabaya Timur dan termasuk daerah perkotaan dengan tipe pemukiman padat. Dimana kondisi tersebut dapat mempengaruhi kondisi sirkulasi udara di dalam rumah, karena pertukaran udara tidak dapat berjalan dengan baik, sehingga dapat mengganggu kondisi 
kesehatan penghuni di dalam rumah tersebut.

Dari data tersebut diatas, maka penulis tertarik untuk melakukan penelitian yang bertujuan untuk mengetahui hubungan sanitasi rumah dengan kejadian penyakit TBC di Wilayah Kerja Puskesmas Pacarkeling Kota Surabaya Tahun 2018.

\section{B. Metode Penelitian}

Penelitian ini menggunakan pendekatan Case Control yaitu suatu penelitian analitik yang menyangkut bagaimana faktorfaktor risiko dipelajari (Notoatmodjo, 2014).

Populasi penelitian ini adalah seluruh rumah penderita TBC BTA (+) yang berada di wilayah kerja Puskesmas Pacarkeling Kota Surabaya yang berjumlah
47 rumah, maka sampel rumah di wilayah kerja Puskesmas Pacarkeling diperoleh hasil sebanyak 42 rumah. Untuk sampel kontrol diambil dengan proporsi 1:1 dengan sampel kasus. Sampel kontrol disini yaitu rumah tetangga penderita yang dijadikan sampel kasus di wilayah kerja puskesmas Pacarkeling Kota Surabaya.

Teknik pengambilan sampel dilakukan dengan cara random sampling. Penilaian terhadap kondisi kesehatan rumah didasarkan pada formulir kartu rumah sehat Dinas Kesehatan dengan menggunakan sistem scoring. Kemudian Dalam penelitian ini digunakan uji ChiSquare, untuk mengetahui adanya hubungan antar variabel.

\section{Hasil dan Pembahasan}

Tabel 1. REKAPITULASI HUBUNGAN SANITASI RUMAH DENGAN KEJADIAN PENYAKIT TBC DI WILAYAH KERJA PUSKESMAS PACARKELING KOTA SURABAYA TAHUN 2018 


\begin{tabular}{|c|c|c|c|c|c|c|c|c|c|}
\hline \multirow[t]{3}{*}{ No } & \multirow[t]{3}{*}{ Variabel } & \multirow[t]{3}{*}{ Kategori } & \multicolumn{4}{|c|}{ Rumah } & \multicolumn{2}{|c|}{ Jumlah } & \multirow[t]{3}{*}{$P$ value } \\
\hline & & & \multicolumn{2}{|c|}{ Penderita } & \multicolumn{2}{|c|}{ Kontrol } & \multirow[b]{2}{*}{$\mathbf{n}$} & \multirow[b]{2}{*}{$\%$} & \\
\hline & & & $\mathbf{n}$ & $\%$ & $\mathbf{n}$ & $\%$ & & & \\
\hline \multirow[t]{3}{*}{1.} & Ventilasi & $\begin{array}{l}\text { Memenuhi } \\
\text { Syarat }\end{array}$ & 7 & 8,3 & 0 & 0 & 7 & 8,3 & 0,006 \\
\hline & & $\begin{array}{l}\text { Tidak } \\
\text { Memenuhi } \\
\text { Syarat }\end{array}$ & 35 & 41,7 & 42 & 50 & 77 & 91,7 & \\
\hline & \multicolumn{2}{|c|}{ Jumlah } & 42 & 50 & 42 & 50 & 84 & 100 & \\
\hline \multirow[t]{2}{*}{2.} & Suhu & $\begin{array}{l}\text { Memenuhi } \\
\text { Syarat }\end{array}$ & 13 & 15,5 & 28 & 33,3 & 41 & 48,8 & 0,001 \\
\hline & & $\begin{array}{l}\text { Tidak } \\
\text { Memenuhi } \\
\text { Syarat }\end{array}$ & 29 & 34,5 & 14 & 16,7 & 43 & 51,2 & \\
\hline \multicolumn{3}{|c|}{ Jumlah } & 42 & 50 & 42 & 50 & 84 & 100 & \\
\hline \multirow[t]{2}{*}{3.} & Kelembaban & $\begin{array}{l}\text { Memenuhi } \\
\text { Syarat }\end{array}$ & 13 & 15,5 & 28 & 33,3 & 41 & 48,8 & 0,001 \\
\hline & & $\begin{array}{l}\text { Tidak } \\
\text { Memenuhi } \\
\text { Syarat }\end{array}$ & 29 & 34,5 & 14 & 16,7 & 43 & 51,2 & \\
\hline \multicolumn{3}{|c|}{ Jumlah } & 42 & 50 & 42 & 50 & 84 & 100 & \\
\hline \multirow[t]{3}{*}{4.} & Pencahayaan & $\begin{array}{l}\text { Memenuhi } \\
\text { Syarat }\end{array}$ & 15 & 17,9 & 30 & 35,7 & 45 & 53,6 & 0,001 \\
\hline & & $\begin{array}{l}\text { Tidak } \\
\text { Memenuhi } \\
\text { Syarat }\end{array}$ & 27 & 32,1 & 12 & 14,3 & 39 & 46,4 & \\
\hline & \multicolumn{2}{|c|}{ Jumlah } & 42 & 50 & 42 & 50 & 84 & 100 & \\
\hline \multirow[t]{2}{*}{5.} & $\begin{array}{l}\text { Kepadatan } \\
\text { Hunian }\end{array}$ & $\begin{array}{l}\text { Memenuhi } \\
\text { Syarat }\end{array}$ & 8 & 9,5 & 16 & 19 & 24 & 28,6 & 0,053 \\
\hline & Rumah & $\begin{array}{l}\text { Tidak } \\
\text { Memenuhi } \\
\text { Syarat }\end{array}$ & 34 & 40,5 & 26 & 31 & 60 & 71,4 & \\
\hline \multicolumn{3}{|c|}{ Jumlah } & 42 & 50 & 42 & 50 & 84 & 100 & \\
\hline \multirow[t]{3}{*}{6.} & $\begin{array}{l}\text { Kebiasaan } \\
\text { Membuka }\end{array}$ & $\begin{array}{l}\text { Memenuhi } \\
\text { Syarat }\end{array}$ & 14 & 16,7 & 29 & 34,5 & 43 & 51,2 & 0,001 \\
\hline & Jendela & $\begin{array}{l}\text { Tidak } \\
\text { Memenuhi } \\
\text { Syarat }\end{array}$ & 28 & 33,3 & 13 & 15,5 & 41 & 48,8 & \\
\hline & \multicolumn{2}{|c|}{ Jumlah } & 42 & 50 & 42 & 50 & 84 & 100 & \\
\hline \multirow[t]{4}{*}{7.} & Sanitasi & Baik & 7 & 8,3 & 26 & 31 & 33 & 39,3 & 0,000 \\
\hline & Rumah & Cukup & 34 & 40,5 & 16 & 19 & 50 & 59,5 & \\
\hline & & Kurang & 1 & 1,2 & 0 & 0 & 1 & 1,2 & \\
\hline & \multicolumn{2}{|c|}{ Jumlah } & 42 & 50 & 42 & 50 & 84 & 100 & \\
\hline
\end{tabular}


1. Hubungan Ventilasi dengan kejadian Penyakit TBC

Pada tabel diatas dapat diketahui bahwa ventilasi yang memenuhi syarat dengan kejadian TBC sebanyak 7 rumah $(8,3 \%)$, dan ventilasi yang tidak memenuhi syarat dengan kejadian TBC sebanyak 35 rumah $(41,7 \%)$. Sedangkan untuk ventilasi yang memenuhi syarat dengan tidak disertai kejadian TBC sebanyak 0 rumah (0\%) dan ventilasi yang tidak memenuhi syarat dengan tidak disertai kejadian TBC sebanyak 42 rumah (50\%).

Berdasarkan hasil uji statistik yaitu uji Chi-Square yang menyatakan bahwa ada hubungan ventilasi dengan dengan kejadian penyakit TBC di wilayah kerja Puskesmas Pacarkeling Kota Surabaya ( $P$ 0,006 < 0,05). Menurut Febrian (2015), luas ventilasi yang tidak memenuhi syarat kesehatan

akan

mengakibatkan terhalangnya

proses pertukaran aliran udara dan sinar matahari yang masuk ke dalam rumah, akibatnya kuman tuberculosis yang ada di dalam rumah tidak dapat keluar dan ikut terhisap bersama udara pernafasan.

2. Hubungan Suhu dengan Kejadian Penyakit TBC

Pada tabel diatas dapat diketahui bahwa suhu yang memenuhi syarat dengan kejadian TBC sebanyak 13 rumah $(15,5 \%)$, dan suhu yang tidak memenuhi syarat dengan kejadian TBC sebanyak 29 rumah (34,5\%). Sedangkan untuk suhu yang memenuhi syarat dengan tidak disertai kejadian TBC sebanyak 28 rumah $(33,3 \%)$ dan suhu yang tidak memenuhi syarat dengan tidak disertai kejadian TBC sebanyak 14 rumah $(16,7 \%)$. 
Berdasarkan uji statistik yaitu uji Chi-Square yang menyatakan bahwa ada hubungan antara suhu dengan kejadian penyakit TBC di wilayah kerja Puskesmas Pacarkeling Kota Surabaya ( $P$ $0,001<0,05)$. menurut Ruswanto (2010), bakteri Mycobacterium tuberculosis memiliki rentang suhu yang disukai, yang mana akan tumbuh subur dalam rentang $25-40^{\circ} \mathrm{C}$, akan tetapi akan tumbuh secara optimal pada suhu $31-37^{\circ} \mathrm{C}$. Suhu udara yang cukup segar dalam rumah umumnya berkisar antara $22-30^{\circ} \mathrm{C}$.

3. Hubungan Kelembaban dengan Kejadian Penyakit TBC Pada tabel diatas dapat diketahui bahwa kelembaban yang memenuhi syarat dengan kejadian TBC sebanyak 13 rumah $(15,5 \%)$ dan kelembaban yang tidak memenuhi syarat dengan kejadian TBC sebanyak 29 rumah (34,5\%). Sedangkan untuk kelembaban yang memenuhi syarat dengan tidak disertai kejadian TBC sebanyak 28 rumah $(33,3 \%)$ dan kelembaban yang tidak memenuhi syarat dengan tidak disertai kejadian TBC sebanyak 14 rumah (16,7\%).

Berdasarkan uji statistik yaitu uji Chi-Square yang menyatakan bahwa ada hubungan antara kelembaban dengan kejadian penyakit TBC di wilayah kerja Puskesmas Pacarkeling Kota Surabaya (P $0,001<0,05)$. Sedangkan menurut Febrian (2015), rumah yang lembab merupakan media yang baik bagi pertumbuhan mikroorganisme serta bakteri Mycobacterium tuberculosis seperti halnya bakteri lain, akan tumbuh dengan subur pada lingkungan dengan kelembaban tinggi. 
4. Hubungan Pencahayaan dengan Kejadian Penyakit TBC

Pada tabel diatas dapat diketahui bahwa pencahayaan yang memenuhi syarat dengan kejadian TBC sebanyak 15 rumah $(17,9 \%)$, dan pencahayaan yang tidak memenuhi syarat dengan kejadian TBC sebanyak 27 rumah $(32,1 \%)$. Sedangkan untuk pencahayaan yang memenuhi syarat dengan tidak disertai kejadian TBC sebanyak 30 rumah $(35,7 \%)$ dan pencahayaan yang tidak memenuhi syarat dengan tidak disertai kejadian TBC sebanyak 12 rumah (14,3\%).

Berdasarkan uji statistik yaitu uji Chi-Square yang menyatakan bahwa ada hubungan antara pencahayaan dengan kejadian penyakit TBC di wilayah kerja Puskesmas Pacarkeling Kota Surabaya ( $P$ $0,001<0,05)$. Menurut Dora (2011), fungsi sinar matahari yang masuk ke dalam rumah yaitu untuk memperlancar aliran udara serta untuk membunuh bakteri dan virus yang ada di dalam rumah.

5. Hubungan Kepadatan Hunian Rumah dengan Kejadian Penyakit TBC

Pada tabel diatas dapat diketahui bahwa kepadatan hunian rumah yang memenuhi syarat dengan kejadian TBC sebanyak 8 rumah $(9,5 \%)$, dan kepadatan hunian rumah yang tidak memenuhi syarat dengan kejadian TBC sebanyak 34 rumah (40,5\%). Sedangkan untuk kepadatan hunian rumah yang memenuhi syarat dengan tidak disertai kejadian TBC sebanyak 16 rumah (19\%) dan kepadatan hunian rumah yang tidak memenuhi syarat dengan tidak disertai kejadian TBC sebanyak 26 rumah (31\%).

Berdasarkan uji statistik yaitu uji Chi-Square yang 
menyatakan bahwa tidak ada hubungan antara kepadatan hunian rumah dengan kejadian penyakit TBC di wilayah kerja Puskesmas Pacarkeling Kota Surabaya ( $P$ 0,053 > 0,05). Menurut Ruswanto (2010), Luas rumah yang tidak sebanding dengan jumlah anggota keluarga akan menyebabkan over crowded.

6. Hubungan

Kebiasaan

Membuka Jendela dengan Kejadian Penyakit TBC

Pada tabel diatas dapat diketahui bahwa kebiasaan membuka jendela yang memenuhi syarat dengan kejadian TBC sebanyak 14 rumah $(16,7 \%)$, dan kebiasaan membuka jendela yang tidak memenuhi syarat dengan kejadian TBC sebanyak 28 rumah $(33,3 \%)$. Sedangkan untuk kebiasaan membuka jendela yang memenuhi syarat dengan tidak disertai kejadian TBC sebanyak 29 rumah (34,5\%) dan kebiasaan membuka jendela yang tidak memenuhi syarat dengan tidak disertai kejadian TBC sebanyak 13 rumah $(15,5 \%)$.

Berdasarkan uji statistik yaitu uji Chi-Square yang menyatakan bahwa ada hubungan antara kebiasaan membuka jendela dengan kejadian penyakit TBC di wilayah kerja Puskesmas Pacarkeling Kota Surabaya ( $P$ $0,001<0,05)$. Menurut Dirjen P2PL Depkes RI (2009), membuka pintu dan jendela setiap pagi berfungsi agar udara dan sinar matahari dapat masuk ke dalam ruangan.

7. Hubungan Sanitasi Rumah dengan kejadian Penyakit TBC Pada tabel diatas dapat diketahui bahwa sanitasi rumah dengan kejadian TBC yang memiliki kategori baik yaitu sebanyak 7 rumah 
$(8,3 \%)$ r rumah dengan kejadian TBC yang memiliki kategori cukup yaitu sebanyak 34 rumah (40,5\%), dan rumah dengan kejadian TBC yang memiliki kategori kurang yaitu sebanyak 1 rumah (1,2\%). Sedangkan sanitasi rumah dengan tidak disertai kejadian TBC yang memiliki kategori baik yaitu sebanyak 26 rumah (31\%), rumah dengan tidakD. disertai kejadian TBC yang memiliki kategori cukup yaitu sebanyak 16 rumah (19\%), dan rumah dengan tidak disertai kejadian TBC yang memiliki kategori kurang yaitu sebanyak 0 rumah (0\%).

Berdasarkan uji statistik yaitu uji Chi-Square yang menyatakan bahwa ada hubungan antara kondisi rumah dengan kejadian penyakit TBC di wilayah kerja Puskesmas Pacarkeling Kota Surabaya $(P \quad 0,000<0,05)$. Menurut Dinas Perumahan dan
Pemukiman RI (2008), rumah adalah tempat tinggal yang memenuhi ketetapan atau ketentuan teknis kesehatan yang wajib dipenuhi dalam rangka melindungi penghuni rumah dari bahaya atau gangguan kesehatan, sehingga memungkinkan penghuni memperoleh derajat kesehatan yang optimal.

\section{Kesimpulan}

1. Ada hubungan ventilasi dengan dengan kejadian penyakit TBC di wilayah kerja Puskesmas Pacarkeling Kota Surabaya.

2. Ada hubungan antara suhu dengan kejadian penyakit TBC di wilayah kerja Puskesmas Pacarkeling Kota Surabaya.

3. Ada hubungan antara kelembaban dengan kejadian penyakit TBC di wilayah kerja Puskesmas Pacarkeling Kota Surabaya.

4. Ada hubungan antara pencahayaan dengan kejadian penyakit TBC di wilayah kerja 
Puskesmas Pacarkeling Kota Surabaya.

5. Tidak ada hubungan antara kepadatan hunian rumah dengan kejadian penyakit TBC di wilayah kerja Puskesmas Pacarkeling Kota Surabaya.

6. Ada hubungan antara kebiasaan membuka jendela dengan kejadian penyakit TBC di wilayah kerja Puskesmas Pacarkeling Kota Surabaya.

7. Ada hubungan antara kondisi rumah dengan kejadian penyakit TBC di wilayah kerja Puskesmas Pacarkeling Kota Surabaya.

\section{E. Saran}

1. Bagi Puskesmas Pacarkeling dapat melakukan program rumah sehat seperti diadakan perlombaan rumah sehat di setiap RT dan program bersih- bersih rumah secara bersamaan disetiap RT/RW.

2. Bagi masyarakat disarankan untuk lebih memperhatikan kembali pentingnya kondisi rumah sehat, seperti rutin untuk membuka jendela ruang keluarga dan kamar tidur agar sirkulasi udara dapat berjalan dengan baik. Selain itu memisahkan alat makan bagi anggota keluarga yang menderita TBC

3. Bagi peneliti lain dapat digunakan sebagai bahan referensi atau pertimbangan yang terkait dengan penelitian sejenis mengenai upaya penyehatan lingkungan pemukiman yang berkaitan dengan hubungan kondisi rumah dengan kejadian penyakit TBC. 


\section{DAFTAR PUSTAKA}

Crysta, Elpidia Agatha. 2017. Analisis Febrian, Mira Ayu. 2015. FaktorTingkat Kekumuhan Dan Pola Penanganannya (Studi Kasus:

Kelurahan Keputih, Surabaya).

Fakultas Teknik Sipil dan

Perencanaan: Institut Teknologi

Sepuluh Nopember Surabaya

Dinas Perumahan dan Pemukiman

Republik Indonesia Tahun 2008

Direktorat Jenderal Pengendalian

Penyakit dan Penyehatan

Lingkungan Departemen

Kesehatan Republik Indonesia

Tahun 2009

Dora, Purnama Esa. 2011.

Pemanfaatan Pencahayaan

Alami pada Rumah Tinggal Tipe

Townhouse di Surabaya.

faktor yang Berhubungan dengan Kejadian TB Paru Anak di Wilayah Puskesmas Garuda Kota Bandung. 2 (3): 64 - 79

Notoatmodjo, Soekidjo. 2014. Metodologi Penelitian Kesehatan. Jakarta: PT Rineka Cipta

Ruswanto, Bambang. 2010. Analisis Spasial Sebaran Kasus Tuberkulosis Paru Ditinjau dari Faktor Lingkungan Dalam dan Luar Rumah di Kecamatan Pakalongan.

WHO. 2014. Global Tuberculosis Report 2014. Jenewa: World Heah Organization. 